ISSN 1412-2936

EISSN 2549-7308

\title{
PENGARUH VARIABEL BAURAN PEMASARAN TERHADAP KEPUTUSAN KONSUMEN MEMBELI PASTA GIGI PEPSODENT PT. UNILEVER INDONESIA, TBK
}

\author{
Andriandita Wijayanto \\ Universitas Yos Sudarso
}

\begin{abstract}
ABSTRAK
Memahami perilaku konsumen dalam memilih produk, pemasar dapat memahami dengan sebenarnya apa yang menjadi kebutuhan dan keinginan konsumen, latar belakang konsumen, alasan melakukan pembelian produk. Untuk itu penelitian ini bertujuan untuk mengetahui pengaruh Variabel Bauran Pemasaran Terhadap Keputusan Konsumen Membeli Pasta Gigi Pepsodent.

Populasi penelitian adalah konsumen pengguna pasta gigi dengan kemasan merek Pepsodent, dengan memilih sampel 100 orang melalui teknik purposive sampling. Analisis dilakukan melalui teknik regresi ganda, yang hasilnya menunjukkan bahwa variabel bauran pemasaran berpengaruh simultan terhadap keputusan konsumen untuk membeli, hal ini dibuktikan dengan nilai $p=0,000$ $(p<0,05)$. Pengujian hipotesis juga menunjukan bahwa produk berpengaruh positif terhadap keputusan pembelian, dengan nilai $p=0,042(p<0,05)$, sedangkan faktor harga berpengaruh positif terhadap keputusan pembelian, yang ditunjukan dengan nilai $p=0,000(p<0,05)$. Selanjutnmya faktor distribusi berpengaruh positif terhadap keputusan pembelian, dengan nilai $p=0,000 \quad(p<0,05)$, serta faktor promosi berpengaruh positif terhadap keputusan pembelian, dengan nilai $\mathrm{p}=0,001(\mathrm{p}$ $<0,05)$.
\end{abstract}

Kata Kunci : Produk, Harga, Distribusi, Promosi dan Keputusan Pembelian 


\section{Pendahuluan}

Pesan kampanye yang konsisten di beberapa saluran membantu orang mengubah kebiasaan mereka. Pada tahun 2012, orang Indonesia menggunakan $7 \%$ pasta gigi lebih banyak dibandingkan tahun 2011, yang menunjukkan peningkatan kebiasaan menggosok gigi sedikit demi sedikit. Ekuitas brand juga meningkat. Dengan menawarkan produk yang efektif kepada orang tua dan dengan membantu mereka menanamkan kebiasaan menggosok gigi siang dan malam hari, kami sudah meningkatkan proporsi orang yang menilai Pepsodent sebagai 'pasta gigi yang paling efektif'.

$$
\text { Brand pasta gigi }
$$

kesehatan keluarga terdepan, Signal dan Pepsodent, berkembang pesat berkat kampanye kesehatan mulut Sikat Gigi Siang dan Malam. Pada tahun 2008-12, Signal tumbuh sebesar $22 \%$ di seluruh dunia. Di Indonesia, salah satu pasar terbesar kami, penjualan Pepsodent meningkat hampir 16\% di tahun 2012 dibandingkan tahun sebelumnya. Menghadapi kenyataan ini produsen pasta gigi Pepsodent dituntut untuk mendefinisikan kembali pelanggan-nya, menarik pelanggan baru dan lebih spesifik dalam memilih segmen pasar agar tetap bisa mempertahankan kelangsungan hidupnya. Produsen pasta gigi Pepsodent harus berupaya untuk mendapatkan perhatian konsumen-nya melalui promosi.

Keberhasilan pemasaran suatu produk tergantung pada kemampuan produk itu untuk memenuhi kebutuhan dan keinginan konsumen-nya. Konsumen dalam melakukan pembelian

selalu

memperhatikan jenis produk yang dibeli yang dapat dibedakan dari harga, ukuran, penampilan atau atribut yang lain. Oleh sebab itu dalam memproduksi barang dan jasa, perusahaan selalu berusaha agar barang dan jasa yang dihasilkan sesuai dengan selera pasar atau konsumen. Namun pada kenyataan-nya walaupun produk yang dihasilkan sudah disesuaikan dengan selera konsumen melalui penyesuaian harga, akan tetapi kemudian perusahaan menjadi kecewa karena produknya tidak laku terjual. Hal ini disebabkan karena produk belum tersedia di pasar sehingga belum dikenal dengan baik oleh masyarakat konsumen.

Untuk mengatasi hal ini, kegiatan pemasaran lebih ditingkatkan lagi melalui variabel lain dari bauran pemasaran (marketing mix) selain variabel produk, harga, distribusi, promosi, proses, people dan physical environment. Dengan demikian kegiatan pemasaran tidak hanya meliputi perbaikan kualitas produk, harga yang terjangkau dan saluran distribusi yang baik, akan tetapi juga meliputi kegiatan promosi yang diketahui sangat penting dalam menunjang usaha pemasaran. Melalui kegiatan bauran promosi periklanan perusahaan dapat memperkenalkan produk yang dihasilkan dan memberikan informasi kepada konsumen tentang kehadiran, manfaat dan keunggulan dari produk itu. Selain jenis produk yang mempengaruhi keputusan konsumen membeli, variabel harga merupakan penentu utama didalam hal keputusan konsumen membeli. Pilihan konsumen akan jatuh pada produk yang harga dan 
kualitasnya sesuai dengan kemampuan dana dan keinginan-nya dibandingkan dengan harga tinggi untuk kualitas produk yang sama.

Dalam upaya menanamkan merk didalam ingatan konsumen agar produk bisa selalu diingat, diperlukan kegiatan bauran promosi periklanan. Periklanan merupakan alat komunikasi yang sangat efektif antara produsen dan konsumen yang dipakai sebagai sarana untuk mengingatkan dan mendorong konsumen untuk melakukan pembelian. Iklan yang dilakukan secara berkelanjutan disertai dengan upaya peningkatan kualitas produk, akan meningkatkan posisi produk dalam ingatan konsumen sehingga mampu mempengaruhi mereka untuk melakukan pembelian. Dengan demikian kegiatan bauran pemasaran (marketing mix) apabila dilaksanakan secara terpadu dan tepat akan mampu menempatkan produk pada memori ingatan konsumen. Dari top of mind brand nampaknya proses menuju brand loyalty akan semakin terwujud apabila konsumen yang sudah loyal pada suatu produk diwujudkan melalui kemauan mereka untuk selalu melakukan pembelian berulang.

Agar pasokan pasta gigi Pepsodent selalu lancar dan tersedia dengan cukup di pedagang eceran, warung PKL, toko-toko kelontong dan swalayan maka fungsi armada penjualan perusahaan sangat penting selain efektif juga sangat efisien. Dengan tersedianya pasta gigi Pepsodent dalam jumlah yang cukup memungkinkan konsumen mudah memperolehnya sehingga tidak beralih pada produk lain. Untuk menginformasikan kehadiran serta keunggulan produk kepada konsumen diperlukan suatu bauran promosi. Variabel bauran promosi yang sering dan paling efektif sebagai sarana komunikasi adalah periklanan (advertising). Dengan memasang iklan secara berkelanjutan akan membuat konsumen akan selalu ingat akan produk yang ditawarkan sehingga hal demikian akan mendorong konsumen baru untuk membeli atau konsumen loyalis melakukan pembelian berulang.

Melalui

uraian

sebagaiamana telah dipaparkan, perlu dilakukan penelitian untuk membuktikan pengaruh variabel bauran pemasaran yang meliputi produk, harga, distribusi, promosi, proses, people dan physical environment terhadap keputusan membeli pasta gigi Pepsodent pada PT. Unilever Indonesia Tbk. Atas dasar itu, penelitian ini dilakukan dengan judul Pengaruh Variabel Bauran Pemasaran Terhadap Keputusan Konsumen Membeli Pasta Gigi PT. Unilever Indonesia TBK.

\section{Tujuan Penelitian}

Berdasarkan

latar belakang dan rumusan masalah yang diteliti, maka tujuan yang hendak dicapai dalam penelitian ini adalah sebagai berikut :

1) Untuk menganalisis besarnya pengaruh variabel bauran pemasaran yang meliputi produk, harga, distribusi dan periklanan secara simultan mempengaruhi keputusan konsumen membeli pasta gigi Pepsodent pada PT. Unilever Indonesia Tbk.

2) Untuk menganalisis besarnya pengaruh variabel 
bauran pemasaran yang meliputi produk, harga, distribusi dan periklanan secara parsial mempengaruhi keputusan konsumen membeli pasta gigi Pepsodent pada PT. Unilever Indonesia Tbk.

3) Untuk menganalisis variabel bauran pemasaran yang dominan mempengaruhi keputusan konsumen membeli pasta gigi Pepsodent pada PT. Unilever Indonesia Tbk.

\section{Kajian Teori}

\subsection{Pemasaran}

Definisi tradisional, sebuah pasar adalah tempat fisik di mana pembeli dan penjual berkumpul untuk membeli dan menjual barangbarang. ekonom menggambarkan pasar sebagai kumpulan pembeli dan penjual yang bertransaksi di atas produk tertentu atau kelas produk (seperti pasar perumahan atau pasar gandum). Pemasaran adalah proses sosial dan manajerial untuk memenuhi kebutuhan / keinginan pasar. Proses ini mencakup penciptaan, penawaran dan pertukaran nilai. Pemasaran didefinisikan sebagai mengelola pasar untuk menjalin hubungan yang menguntungkan dengan pelanggan.

Namun, menciptakan hubungan yang membutuhkan kerja. Penjual harus mencari pembeli, mengidentifikasi kebutuhan mereka, merancang penawaran pasar yang baik, menetapkan harga bagi produk, mempromosikan produk, menyimpan dan memberikan produk. Aktifitas seperti riset konsumen, pengembangan produk, komunikasi, distribusi, harga dan pelayanan adalah kegiatan inti pemasaran (Kotler dan Armstrong 2013). Manajemen pemasaran sebagai seni dan ilmu memilih pasar sasaran dan mendapatkan, menjaga dan menumbuhkan pelanggan melalui penciptaan, memberikan dan mengkomunikasikan nilai pelanggan yang unggul. Dan kita dapat mendefinisikan bahwa pemasaran adalah suatu proses sosial dimana individu dan kelompok mendapatkan apa yang mereka butuhkan dan inginkan melalui penciptaan, menawarkan dan secara bebas bertukar produk dan jasa yang bernilai dengan orang lain.

Manajemen pemasaran adalah proses perencanaan dan pelaksanaan dari perwujudan, pemberian harga, promosi dan distribusi barang/jasa dan gagasan untuk menciptakan pertukaran dengan kelompok sasaran yang memenuhi tujuan pelanggan dan organisasi" (Kotler dan Susanto, 1999). Definisi ini mengakui, bahwa manajemen pemasaran yaitu proses yang melibatkan analisa, perencanaan, pelaksanaan, dan pengendalian yang mencakup barang dan jasa, serta gagasan yang tergantung pada pertukaran dengan tujuan menghasilkan kepuasan bagi pihak-pihak yang terkait.

$\begin{array}{lr}\text { Kotler dalam } & \begin{array}{r}\text { Swastha } \\ \text { dan Irawan } \\ (2005: 7)\end{array} \\ \text { mengemukanan, bahwa } \\ \text { manajemen pemasaran } \\ \text { adalah penganalisaan, } \\ \text { perencanaan, pelaksanaan, }\end{array}$


dan pengawasan programprogram yang ditujukan untuk mengadakan pertukaran dengan pasar yang dituju dengan maksud untuk mencapai tujuan organisasi.

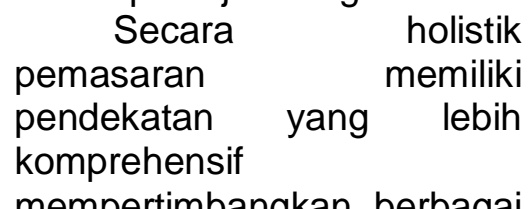

mempertimbangkan berbagai aspek yang saling berkaitan dan mempengaruhi kegiatan pemasaran. Pemasaran holistik mengandung empat komponen yaitu : relationship marketing, integrated marketing, internal marketing dan social responsible marketing. Relationship marketing bertujuan untuk membangun hubungan jangka panjang yang saling memuaskan dengan lini pokok untuk mendapatkan dan mempertahankan bisnis mereka. Pemasaran terpadu adalah untuk merancang kegiatan pemasaran dan merakit program pemasaran yang terintegrasi untuk menciptakan, berkomunikasi dan memberikan nilai bagi konsumen. kegiatan pemasaran datang dalam segala bentuk. McCarthy mengklasifikasikan kegiatan ini sebagai alat pemasarancampuran empat secara luas yang disebut empat P (4 P's) pemasaran: produk, harga, tempat dan promosi. Internal marketing memastikan bahwa setiap orang dalam organisasi menganut prinsipprinsip pemasaran yang tepat, terutama manajemen senior. internal marketing adalah tugas mempekerjakan, pelatihan dan memotivasi karyawan mampu yang ingin melayani pelanggan juga. Pintar pemasar mengakui bahwa kegiatan pemasaran dalam perusahaan dapat sama pentingnya atau bahkan lebih penting daripada kegiatan diarahkan di luar perusahaan pemasaran. tidak masuk akal untuk menjanjikan pelayanan prima sebelum staf perusahaan siap untuk memberikan itu.

Konsep bauran

pemasaran merupakan alat yang dikembangkan dengan baik dipakai sebagai struktur oleh para pemasar. Integrasi unsur-unsur bauran pemasaran memastikan bahwa ada konsistensi di dalam strategi pemasaran secara keseluruhan dan bagaimana mereka dapat memberikan sumber keunggulan kompetitif bagi perusahaan jasa. Bauran pemasaran jasa merupakan alat bagi marketer untuk dapat memasarkan produk yang dihasilkan. Berikut 4 elemen bauran pemasaran menurut Kotler \& Armstrong (2013), yaitu :

a. Produk (Product), dapat berupa kombinasi barang dan jasa yang ditawarkan perusahaan kepada target pasar. produk dapat didefinisikan sebagai sesuatu yang dapat ditawarkan kepada pasar untuk diperhatikan, akuisisi, penggunaan atau konsumsi yang mungkin memuaskan keinginan atau kebutuhan konsumen.

b. Harga (Price), adalah jumlah uang yang dibebankan untuk produk atau layanan yang lebih luas, harga adalah jumlah dari semua nilai-nilai yang pelanggan korbankan untuk mendapatkan manfaat dari memiliki 
atau menggunakan produk atau jasa. Secara historis, harga telah menjadi faktor utama yang mempengaruhi pilihan pembeli. Dalam beberapa dekade terakhir, faktor selain harga semakin dianggap penting. Tetapi harga masih tetap menjadi salah satu elemen yang paling penting yang menentukan pangsa pasar perusahaan dan tingkat keuntungan.

c. Distribusi adalah penyaluran produk dari distributor yang diinginkan oleh penjual untuk dijual / disalurkan kepada konsumen. Misalnya ketersediaan pasta gigi Pepsodent di supermarket / toko besar, dan ketersediaan pasta gigi Pepsodent di swalayan / pedagang eceran.

d. Promosi (Promotion), berarti aktivitas yang mengkomunikasikan manfaat dari produk dan mengajak pelanggan yang dituju untuk membelinya. Bauran promosi perusahaan juga disebut bauran komunikasi pemasaran yang terdiri dari campuran khusus periklanan, hubungan masyarakat, penjualan personal, promosi penjualan dan alat pemasaran langsung yang digunakan perusahaan untuk mengajak mengkomunikasikan nilai pelanggan dan membangun hubungan dengan pelanggan.

\subsection{Keputusan Pembelian}

Pengertian keputusan pembelian, menurut Kotler dan Armstrong (2001) adalah tahap dalam proses pengambilan keputusan pembelian dimana konsumen benar-benar membeli. Pengambilan keputusan merupakan suatu kegiatan individu yang secara langsung terlibat dalam mendapatkan dan mempergunakan barang yang ditawarkan. Mengenai pengambilan keputusan pembelian yang dilakukan oleh konsumen, setiap perusahaan berusaha melakukan pemenuhan kebutuhan yang diinginkan oleh konsumen terutama mengenai produk, harga, distribusi dan periklanan, sehingga konsumen akan selalu tertarik terhadap produk yang dimiliki oleh perusahaan tersebut. Oleh sebab itu, dalam mencari minat konsumen untuk membeli maka pihak manajemen setidaknya harus memiliki informasi sejauh mana variabel-variabel perilaku tersebut berpengaruh terhadap pembelian, maka manajer dapat memilih bauran pemasaran yang tepat. Perusahaan saat ini berupaya untuk mengembangkan berbagai variabel bauran pemasaran.
a. Pertama: dari segi
produk manajer
terus menerus
mencari dan
mengembangkan produk yang sesuai dengan keinginan konsumen.
b. Kedua : dari segi harga, manajer berusaha menentukan harga yang bisa terjangkau oleh




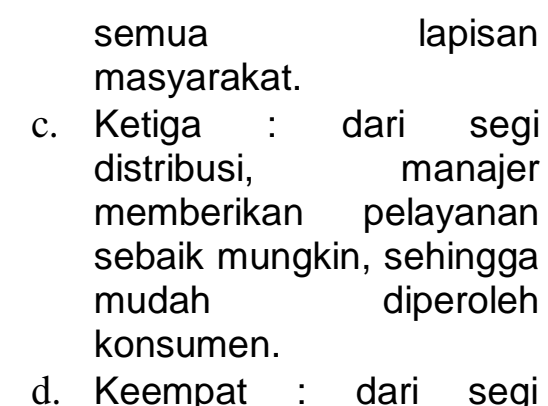

d. Keempat : dari segi
promosi, manajer bisa menyampaikan informasi melalui iklan maupun promosi penjualan. (Gujarati, 1999)

Dari kondisi tersebut di atas, dengan semakin tingginya tingkat pengetahuan dan kesadaran masyarakat terhadap keputusan pembelian, maka membawa pengaruh terhadap perilaku konsumen dalam mengkonsumsi atau menggunakan suatu produk. Di samping itu konsumen memiliki kebebasan dalam memilih produk. Untuk itu produsen memerlukan strategi dengan tujuan mencapai keunggulan bersaing dan memerlukan informasi tentang faktorfaktor yang mempengaruhi perilaku konsumen dalam melakukan pembelian suatu produk.

Keputusan membeli produk pasta gigi pepsodent adalah perilaku perubahan yang dinginkan oleh konsumen terhadap kualitas produk, harga, distribusi, dan periklanan yang meliputi :

a. Kebiasaan / Pemakaian : dalam proses keputusan konsumen membeli pasta gigi Pepsodent karena kebiasaan memakai pasta gigi.

b. Pengaruh Pihak Lain : dalam proses keputusan konsumen membeli pasta gigi Pepsodent dipengaruhi oleh orang lain untuk mendapatkan informasi dari pihak lain.

c. Persepsi akan merk : dalam proses keputusan konsumen membeli karena terpengaruh oleh persepsinya terhadap merk pasta gigi Pepsodent.

\section{Hipotesis}

Berdasarkan rumusan masalah dan landasan teori pada tinjuan pustaka yang telah diuraikan pada bab sebelumnya, maka hipotesis yang diajukan dalam penelitian ini adalah :

$\begin{array}{rr}\text { H1 : Variabel } & \text { bauran } \\ & \text { pemasaran } \\ \text { meliputi } & \text { produk, }\end{array}$ harga, distribusi dan promosi secara simultan mempengaruhi keputusan konsumen membeli pasta gigi Pepsodent pada PT. Unilever Indonesia Tbk.

$\mathrm{H} 2$ : Variabel bauran pemasaran yang meliputi produk, harga, distribusi dan promosi secara parsial mempengaruhi keputusan konsumen membeli pasta gigi Pepsodent pada PT. Unilever Indonesia Tbk.

H3 : Variabel Harga memiliki pengaruh yang dominan terhadap keputusan konsumen membeli pasta gigi Pepsodent.

\section{Metode Penelitian}

5.1 Populasi dan Pengambilan Sampel

Populasi dalam penelitian ini adalah 
ISSN 1412-2936

EISSN 2549-7308

konsumen pasta gigi Pepsoden yang berdomisili di Kota Surabaya bagian Selatan dan sekitarnya. Teknik pengambilan sampel pada penelitian ini menggunakan teknik purposive sampling yaitu sampel yang diambil berdasarkan kriteria tertentu yaitu konsumen yang berjumlah 100 orang.dengan karakteristik sebagai berikut

a. Konsumen pemakai pasta gigi Pepsodent berusia diatas 18 tahun dan berdomisili di kota Surabaya bagian Selatan.

b. Pendidikan terakhir minimal SLTA dengan pertimbangan pada tingkat pendidikan SLTP sudah cukup mempunyai kemampuan untuk memahami kuesioner yang diberikan.

c. Membeli dan memakai pasta gigi Pepsodent selama 1 bulan terakhir.

\subsection{Pengumpulan Data}

Data dikumpulkan melalui kuisioner yang dibagikan kepada responden yang diasumsikan memiliki kemampuan dan memahami pertanyaan- pertanyaan yang tertera. Pengukuran dalam penelitian ini dituangkan dalam kuisioner dengan menggunakan skala Likert, yaitu skala yang digunakan untuk mengukur tanggapan responden terhadap objek penelitian ini dengan bobot 1 sampai dengan 5 .

\subsection{Analisis Data}

Untuk mengetahui apakah variabel bebas yaitu produk (X1), harga (X2) distribusi (X3), dan promosi (X4) mempunyai pengaruh secara simultan terhadap variabel terikat yaitu keputusan konsumen membeli ( $\mathrm{Y}$ ) pasta gigi pepsodent, maka dilakukan pengujian secara simultan dengan uji $F$. Pengujian secara simultan (Uji $F$ ) dilakukan melalui perhitungan dengan bantuan program SPSS yang hasilnya kemudian dibandingan dengan Ftabel. Dalam pengujian hipotesis ini level signifikansi yang digunakan adalah sebesar $5 \%$ atau 0,05 .

\section{ANOVA ${ }^{b}$}

\begin{tabular}{|c|c|c|c|c|c|c|}
\hline Model & & $\begin{array}{c}\text { Sum of } \\
\text { Squares }\end{array}$ & $d f$ & $\begin{array}{l}\text { Mean } \\
\text { Square }\end{array}$ & $F$ & Sig \\
\hline \multirow[t]{3}{*}{1} & $\begin{array}{l}\text { Regressio } \\
n\end{array}$ & 94.003 & 4 & 23.501 & \multirow[t]{3}{*}{$\begin{array}{l}82.97 \\
2\end{array}$} & \multirow[t]{3}{*}{.000} \\
\hline & Residual & 26.907 & 95 & .283 & & \\
\hline & Total & 120.910 & 99 & & & \\
\hline
\end{tabular}

a. Predictors: (Constant), promosi X4, distribusi X3, harga X2, produk X1

b. Dependent Variable: keputusan konsumen $Y$ 
ISSN 1412-2936

EISSN 2549-7308

Menurut perhitungan program SPSS seperti pada tabel berikut diperoleh nilai FHitung sebesar 82,972 sedangkan nilai Ftabel sebesar 2,311 ( $\mathrm{F}>2,311)$. Karena Fhitung sebesar 82,972 lebih besar daripada Ftabel 2,311, maka $\mathrm{H} 0$ ditolak dan Hi diterima, jadi dengan tingkat signifikan 0,000 dapat disimpulkan bahwa secara simultan terdapat pengaruh yang signifikan dari seluruh variabel bebas yaitu produk (X1), harga (X2) distribusi
(X3), dan promosi (X4) terhadap variabel terikat yaitu keputusan konsumen membeli (Y) pasta gigi pepsodent.

Pengujian secara parsial (uji t) dalam penelitian ini digunakan untuk mengetahui variabel bebas manakah di antara variabel produk (X1), harga (X2) distribusi (X3), dan promosi (X4) mempunyai pengaruh secara parsial terhadap variabel terikat yaitu keputusan konsumen membeli (Y) pasta gigi pepsodent.

\begin{tabular}{|c|c|c|c|c|c|}
\hline \multirow{2}{*}{ Model } & \multicolumn{2}{|c|}{$\begin{array}{l}\text { Unstandardi } \\
\text { zed } \\
\text { Coefficient } \\
\text { s } \\
\end{array}$} & \multirow{2}{*}{\begin{tabular}{l} 
Standardiz \\
ed \\
Coefficient \\
s \\
\multicolumn{1}{c}{ Beta }
\end{tabular}} & \multirow{2}{*}{$\mathrm{t}$} & \multirow{2}{*}{ Sig. } \\
\hline & $B$ & $\begin{array}{l}\text { Std } \\
\text { Erro } \\
r\end{array}$ & & & \\
\hline $1 \quad$ (Constant) & .125 & .695 & & .180 & .858 \\
\hline produk X1 & .167 & .081 & .155 & 2.065 & .042 \\
\hline harga X2 & .343 & .076 & .318 & 4.487 & .000 \\
\hline distribusi X3 & .503 & 120 & 296 & 4.176 & .000 \\
\hline promosi X4 & .264 & .076 & .256 & 3.457 & .001 \\
\hline
\end{tabular}


Hasil pengujian secara parsial dapat diketahui sebagai berikut

1) Karena thitung produk (X1) sebesar 2,065 lebih besar daripada ttabel 1,661 maka $\mathrm{HO}$ ditolak dan $\mathrm{Hi}$ diterima, jadi dengan tingkat signifikan 0,042, maka dapat disimpulkan bahwa secara parsial terdapat pengaruh yang signifikan dari faktor variabel bebas yaitu produk terhadap keputusan konsumen membeli pasta gigi pepsodent.

2) Karena thitung harga (X2) sebesar 4,487 lebih besar daripada ttabel 1,661 maka $\mathrm{HO}$ ditolak dan $\mathrm{Hi}$ diterima, jadi dengan tingkat signifikan 0,000, maka dapat disimpulkan bahwa secara parsial terdapat pengaruh yang signifikan dari faktor variabel bebas yaitu harga terhadap keputusan konsumen membeli pasta gigi pepsodent.

3) Karena thitung distribusi (X3) sebesar 4,176 lebih besar daripada ttabel 1,661 maka $\mathrm{HO}$ ditolak dan $\mathrm{Hi}$ diterima, jadi dengan tingkat signifikan 0,000, maka dapat disimpulkan bahwa secara parsial terdapat pengaruh yang signifikan dari faktor variabel bebas yaitu distribusi terhadap keputusan konsumen membeli pasta gigi pepsodent.

4) Karena thitung promosi (X4) sebesar 3,457 lebih

\begin{abstract}
besar daripada ttabel 1,661 maka $\mathrm{HO}$ ditolak dan $\mathrm{Hi}$ diterima, jadi dengan tingkat signifikan 0,001, maka dapat disimpulkan bahwa secara parsial terdapat pengaruh yang signifikan dari faktor variabel bebas yaitu promosi terhadap keputusan konsumen membeli pasta gigi pepsodent.
\end{abstract}

\section{Bahasan}

Seperti yang telah dijabarkan diatas mengenai hasil analisis yang telah dilakukan oleh peneliti, maka peneliti akan memberikan pembahasan dari hasil analisa uji $F$ yang diketahui nilai signifikannya sebesar 0,000 dengan kriteria thitung 82.972 $>$ ttabel 2.311, maka Ho ditolak dan $\mathrm{Hi}$ diterima. Ini berarti bahwa variabel bebas $(X)$ mempunyai pengaruh secara simultan terhadap keputusan konsumen membeli ( $Y$ ) pasta gigi pepsodent. Jadi, dapat disimpulkan bahwa hipotesis mengenai variabel bauran pemasaran yang meliputi produk, harga, distribusi dan promosi secara simultan mempengaruhi keputusan konsumen membeli pasta gigi Pepsodent pada PT. Unilever Indonesia Tbk terbukti kebenarannya.

Sedangkan pada Uji $t$ untuk variabel kualitas produk (X1) mempunyai tingkat signifikansi sebesar 0,042 dengan kriteria thitung $2.065>$ ttabel 1.661, maka Ho ditolak dan $\mathrm{Hi}$ diterima. Untuk variabel bebas harga (X2) mempunyai tingkat signifikansi sebesar 0,000 dengan kriteria thitung 4.487 > ttabel 1.661, maka Ho diterima dan $\mathrm{Hi}$ ditolak. 
Kemudian variabel bebas distribusi (X3) mempunyai tingkat signifikansi sebesar 0,000 dengan kriteria thitung $4.176>$ ttabel 1.661, maka Ho diterima dan $\mathrm{Hi}$ ditolak. Selanjutnya yang terakhir variabel bebas promosi (X4) mempunyai tingkat signifikansi sebesar 0,001 dengan kriteria thitung $3.457>$ ttabel 1.661, maka $\mathrm{Ho}$ diterima dan $\mathrm{Hi}$ ditolak.

Dari pembahasan diatas, dapat dinyatakan bahwa variabel produk (X1), harga (X2) distribusi (X3), dan promosi (X4) memiliki pengaruh secara parsial terhadap variabel terikat keputusan konsumen membeli (Y) pasta gigi pepsodent. Jadi dapat disimpulkan bahwa variabel bauran pemasaran yang meliputi produk, harga, distribusi dan promosi secara parsial mempengaruhi keputusan konsumen membeli pasta gigi Pepsodent pada PT. Unilever Indonesia Tbk terbukti kebenarannya.

Dari hasil analisa uji $\mathrm{t}$ yang telah dijelaskan, maka dapat disimpulkan bahwa variabel harga (X2) memiliki pengaruh yang dominan terhadap keputusan konsumen membeli pasta gigi Pepsodent, sehingga dapat dinyatakan hipotetsis telah terbukti kebenarannya.

\section{Kesimpulan}

Berdasarkan hasil analisis dan pembahasan yang telah dilakukan oleh peneliti, maka dapat disimpulkan sebagai berikut :

1) Hasil pengolahan data penelitian ini dianggap valid dan reliabel (handal). Dilihat dari halis analisa validitas yang menunjukkan rata-rata dari masing- masing variabel lebih besar dari 0,195 jadi dapat dikatakan valid, dan nilai reliabilitas dari masingmasing variabel menunjukkan nilai yang reliabel dengan nilai masing-masing variabel diatas 0,6.

2) Kemudian dari hasil analisa data uji $\mathrm{F}$ dengan tingkat signifikan sebesar 0,000, maka disimpulkan bahwa secara simultan terdapat pengaruh yang signifikan dari seluruh variabel bebas yaitu produk (X1), harga (X2) distribusi (X3), dan promosi (X4) terhadap variabel terikat yaitu keputusan konsumen membeli ( $\mathrm{Y}$ ) pasta gigi pepsodent.

3) Mengenai uji t (uji parsial) dengan tingkat signifikan masing-masing variabel dibawah 0,000, maka disimpulkan bahwa secara parsial terdapat pengaruh yang signifikan dari seluruh variabel bebas yaitu produk (X1), harga (X2) distribusi (X3), dan promosi (X4) terhadap variabel terikat yaitu keputusan konsumen membeli ( $\mathrm{Y}$ ) pasta gigi pepsodent.

\section{Daftar Pustaka}

Arikunto.(1993).Prosedur

Penelitian, Suatu Pendekatan Praktek. Edisi Kesembilan. Jakarta.Rineka Cipta.

Triton Prawira, Budi. (2006). "SPSS 13.0 Terapan Riset Statistik Parametrik".Yogyakarta :Andi Offset.

Everth Kunu, Libreck. (2009). "Pengaruh Variabel Bauran 


\section{Pemasaran Terhadap Keputusan Konsumen Membeli Rokok Filter Universal Pada PT. Bokor Mas Mojokerto". Surabaya :Thesis. Universitas Dr. Soetomo.}

Ferdinand. (2006). "Metode Penelitian Manajemen : Pedoman Penelitian untuk Penulisan Skripsi"

Irawan, Drs. Darto. (2011). "Teori Organisasi \& Knowledge Management". Surabaya :Modul Program Pascasarjana Magister Manajemen. Universitas Dr. Soetomo.

Karunia Sukma, Trymeika. (2007). "Pengaruh Bauran Pemasaran Jasa Terhadap Minat Menggunakan Kembali Jasa Poli Kosmetika Medik Melalui Kepuasan Pelanggan di Rumah Sakit Petrokimia Gresik". Surabaya :Skripsi. Universitas Airlangga.

Kotler, Philip \& Keller, Kevin Lane. (2009).“Marketing Management".13th

Edition.Pearson

International

Edition.Surabaya

:BukuBacaan.Universitas

Airlangga.

Kotler, Philip \& Armstrong, Gary. (2013). "Principles of Marketing". 14th Edition. Pearson Horizon Edition.

Mursinto, Djoko. (2008). "StatistikManajerial",

Surabaya :Modul Program Pascasarjana Magister Manajemen, Universitas Dr. Soetomo.

Singgih, Santoso. (2002). "BukuLatihan SPSS StatistikParametrik", Jakarta :Elex Media Komputindo.
Sudjana, N. (1999). "Tuntunan Penyusunan Karya IImiah, Makalah, Skripsi, Tesis, Disertasi". Bandung : Sinar Baru Algensindo.

Tholib, Mochamad. (2000). "Faktor-faktor yang Mempengaruhi Perilaku Konsumen dalam Keputusan Membeli Sabun Mandi di Kodya Semarang". Surabaya :Thesis. Universitas Airlangga.

Widyastuti, Mita. (2008). "Alasan Masyarakat Tidak Memilih Bank Syariah Ditinjau Dari Aspek Bauran Pemasaran (Studi Pada Masyarakat Kabupaten Pamekasan Madura)" Surabaya : Skripsi. Universitas Airlangga.

Yarnest. (2003). Panduan Aplikasi Statistic dengan menggunakan SPSS 17.00. Malang : DIOMA.

Yudi Setyono, Eko. (2009). "Analisis Faktor -Faktor Bauran Pemasaran Yang Mempengaruhi Keputusan Pembelian Produk Susu Bendera (Studi Pada Konsumen Yang Mengkonsumsi Produk Susu Bendera di Kecamatan Sukolilo Surabaya)". Surabaya :Thesis. Universitas Dr. Soetomo.

Akses Media Internet:

Website Penunjang Online. (2014). Internet http://Google/Search dan http://Wikipedia.org

Website Perusahaan :http://www.unilever.co.id

Penyelarasan Bahasa Penulis. (2014). Internet http://Google/Translate 